\title{
The Indian Policy of Skilled Migration: Brain Return Versus Diaspora Benefits
}

\author{
Alfonso Giordano · Giuseppe Terranova
}

Published online: 6 October 2012

(c) CEEUN 2012

\begin{abstract}
Based on the premise that international migration is a clearest manifestation of globalization, this article aims to analyse in detail the phenomenon of skilled migration. Skilled migrants represent a worldwide group of people that, while not big in number, is exponentially more influential than lower-skilled migrants, given his high rates of innovation and specialization. Within this framework, we decided to examine the case of India: a choice motivated by two main factors. The first is that the number of Indian migrants, and also skilled migrants, has been steadily increasing for several years. So much so that, on a global level, they are the second largest diaspora group, close behind the Chinese. The second reason for focusing on India, in some ways even more relevant, relates to something that is a first for the sub-continent: in the past few decades India has become a destination for significant flows of highly qualified migrants. What are the Indian government's policies, past and present, for capitalising on this opportunity? Are the preferences of New Delhi more supportive of a brain return or do they favour capitalising on the political influence and economic relevance of its own diaspora? These are the main points this article will consider.
\end{abstract}

Keywords Skilled migrations $\cdot$ Migration policies $\cdot$ Remittances $\cdot$ Diaspora Brain return

\footnotetext{
Although this article is the result of the authors' shared ideas, the following paragraphs are attributable to Alfonso Giordano: «India: between skilled migration, economic globalisation and international relations» and «The pervasive soft power of the 'Indiaspora'»; The following paragraphs are attributable to Giuseppe Terranova: «India: from land of emigrants to a land of immigrants» and «Transformation of migratory flows and the role of New Delhi». The conclusions can be considered the work of both authors.
}

\footnotetext{
A. Giordano $(\bowtie) \cdot$ G. Terranova

Department of Political Science, LUISS University, Rome, Italy

e-mail: algiordano@luiss.it
} 


\section{India: Between Skilled Migration, Economic Globalisation and International Relations}

Migratory movements, as noted, are a very important facet of globalisation and interaction between different economies. According to scholars of international politics, and in particular those who ascribe to the ever more influential area of research known as «Global Governance» $(\mathrm{GG})$, international migration represents, through the rapid increase of movement of people and ideas between states, the most clear indication of globalisation in an era that could certainly be defined as turbulent and subject to continual mutations (Counihan and Miller 2006).

This is even more pertinent for skilled migration: a group that is certainly smaller in terms of numbers, but is far more influential and incisive, given the high rate of innovation and specialisation that is characteristic of skilled migrants.

The labour market for qualified personnel is becoming ever-more globalised, both in terms of supply and demand (Lucas 2008). Various factors of push and pull influence the volume, frequency, duration and the direction of the flow of skilled migrants. Traditionally, these flows have been from south to north, ${ }^{1}$ but the vibrancy of some economies in the southern hemisphere-in particular those in east Asia-is increasingly having an effect on established migratory routes. This is happening to such as extent that migratory flows are now evident in various other directions: north-north, north-south and south-south. Not only are these movements over greater geographical distances, but they also involve greater numbers of people and are occurring more frequently. This has naturally been made possible by the prevalence of information and communication technologies, and from the development of transport infrastructure. Furthermore, two very important variables-on one hand demographic dynamics and, on the other, economic circumstances-are destined to shape migratory flows in the coming years.

In the first phase, the mobility of skilled human capital has been a matter of prerogative for states. Today, it has become evident that not only states, but also other entities, such as regions, cities, universities and multinationals, are all competing on a global market to ensure they are attractive to skilled and qualified workers of various professional sectors. Every kind of institution has therefore been obliged to adopt management policies that will ensure their own attractiveness, both domestically and abroad, depending on the type of skilled human capital they are hoping to attract.

Migration generally and the international mobility of qualified workers are in fact more complex to analyse, understand and to categorise than the movement of resources, products or money; they involve many more factors, circumstances and human variables. Every skilled group is therefore motivated by different push and pull factors, and should be targeted with appropriate, specific policies, tailored as far as possible for each sector (Mahroum 1999). This is true at both the micro and intermediate levels - cities, universities, multinationals, regions-as well as on the macro, state level, which, being increasingly exposed to various international pressures, are or should be concerned for their well-being.

\footnotetext{
${ }^{1}$ Not to forget that the term «brain drain» was coined by the Royal Society to refer to the post-war emigration of scientists from Europe to the US.
} 
Many developing countries have liberalised their policies to facilitate the immigration of qualified workers, and to position themselves more competitively for brain gain. However it should be noted that the supply of skilled human capital continues to come mainly from developing countries, entailing an exodus of their most highly skilled workers. Although a certain quota of skilled migration (what economists call optimal brain drain) is required to better integrate developing countries into the global economy, an excessive outflow of highly skilled professionals may have a negative effect on national growth and development (Lowell and Findlay 2001). This growth and development depends, in today's globalised economy, not only on the domestic qualified human capital present in each country, but also on the continuous links, and the related benefits, that states are able to maintain with their skilled citizens abroad. Considering the ever more intense inter-connection between different economies, this is true for both developing and developed countries.

Ultimately, the main question is not whether skilled migration is «good» or «bad». Rather, it regards the role of skilled migration in the process of globalisation and the conditions under which various countries, with the appropriate policies, can benefit.

In this scenario, India plays a leading role. The number of Indian migrants, especially those with qualifications, has progressively increased. In 2010, India recorded 11.4 million departures: the second highest number of emigrants after Mexico, with 11.9 million (World Bank 2011). In absolute terms, India is one of the main suppliers of qualified personnel to international markets. The country's skilled human capital abroad is highly varied and covers almost all fields of activity, though there is a prevalence in IT and the medical sector. India is also a prime supplier of one of the primary sources of skilled human capital, i.e., students. Along with China, it is the main exporter of international students (Hawthorne 2008). The geographic coverage and destinations of Indian migrants is varied and differentiated, with two areas of preference: less qualified migrants tend to move towards the Persian Gulf, while more highly-qualified migrants head for traditional destinations such as the US, Canada and Britain, although other European countries are now receiving increasing quotas of Indians (Khadria 2006).

The departure of high numbers of highly-qualified personnel from India, in the 1960s and '70s, has naturally raised the question of a brain drain that is damaging for the country. This concern drove India's emergence as a «brain bank» during the ' 80 s and '90s. By the twenty-first century, scholars were instead referring to brain gain (Buga and Meyer 2012). This was due in part to the return of some highlyqualified Indians to their native country, but moreover to the influential global role of the Indian diaspora, ${ }^{2}$ not only in economic but also in political terms, which had

\footnotetext{
2 The term «Indian diaspora» refers to people of Indian origin that live outside India, provided that they have maintained some important ethno-cultural Indian characteristics. Citizens of Pakistan and Bangladesh, however, are not included in the Indian diaspora because those countries were part of the wider concept of British India before 1947, and are therefore an exceptional case. A distinction is commonly made between non-resident Indians (NRIs), who have Indian citizenship, and persons of Indian origin (PIO), who do not have Indian citizenship. The Diaspora Services Division of the Ministry of Overseas Indian Affairs (MOIA) deals with matters related to Indians overseas, including PIOs, overseas citizens of India (OCIs), NRIs and overseas Indians who are not PIOs, OCIs or NRIs. The last category includes those overseas Indians whose forefathers migrated from India in the nineteenth and early twentieth century.
} 
beneficial effects on the development of India. It should be reiterated that the Indian diaspora is large-second only to that of China-present in practically all continents, English-speaking, and with a high percentage of qualified migrants, particularly in key sectors such as IT, medicine and advanced services. In a progressively globalised economy in which knowledge is gaining increasing importance, it is evident that India will have a growing role in international relations.

What policies is the Indian government implementing in order to reap maximum benefit from this opportunity? Is New Delhi's preference for brain return or for capitalising on the political influence and economic clout of its diaspora? Before attempting to answer these questions, it is useful to step back and briefly outline the transformation of the profile of migrating Indians, as well as analysing the politics and economic functions of the diaspora.

\section{India: From Land of Emigrants to a Land of Immigrants}

Although India continues to be one of the most important sources of skilled labour for the rest of the world, there are now signs, albeit still weak, of a trend reversal in the country that is now an international power. This is a first for a country that, as shown in the following table, has about 30 million citizens abroad (Wihtol de Wenden 2009), resident mainly in the US, Europe (mostly in the Britain) but also, for example, in the Middle East (3.5 million) (Table 1).

It should be noted that although we are speaking about a country that is growing economically, more than one-third of its population lives on less than one dollar a day, $50 \%$ of infants are malnourished and more than $30 \%$ of citizens are illiterate.

Even so, from the beginning of the third millennium, India has seen a weak but steady increase in the arrival of qualified immigrants as well as an increase of emigrated Indians returning to work in their mother country. What are the reasons behind this phenomenon?

In a nutshell, one could say that this is the umpteenth victory of economics over politics. Contrary to what would be expected of India, following the pattern of other countries, the government in New Delhi has done little or nothing to support this historical reversal. We will discuss this in more depth later in this article. Moreover, the motives for this reverse-trend of qualified migratory flow in an Indian context are to be found in economic factors. There are at least two reasons for this.

The first relates to the current global economic crisis, which has hit western nations in particular and has played a significant role in the decision of the growing numbers of the unemployed in so-called advanced countries, to emigrate towards countries that are currently emerging on the international market, such as India. These countries are now perceived as being very attractive in terms of job opportunities.

The same is true, or even rather more so, of the many Indian expatriates abroad. According to Alwyn Didar Singh, ex-departmental head at the Ministry of Overseas Indians Affairs, more than 100,000 Indians returned to their homeland in 2010 (Semple 2012). According to an article in the FT, India's corporate sector is expected to hire about 35,000 home-comers, or repatriates, this year (Lamont and 


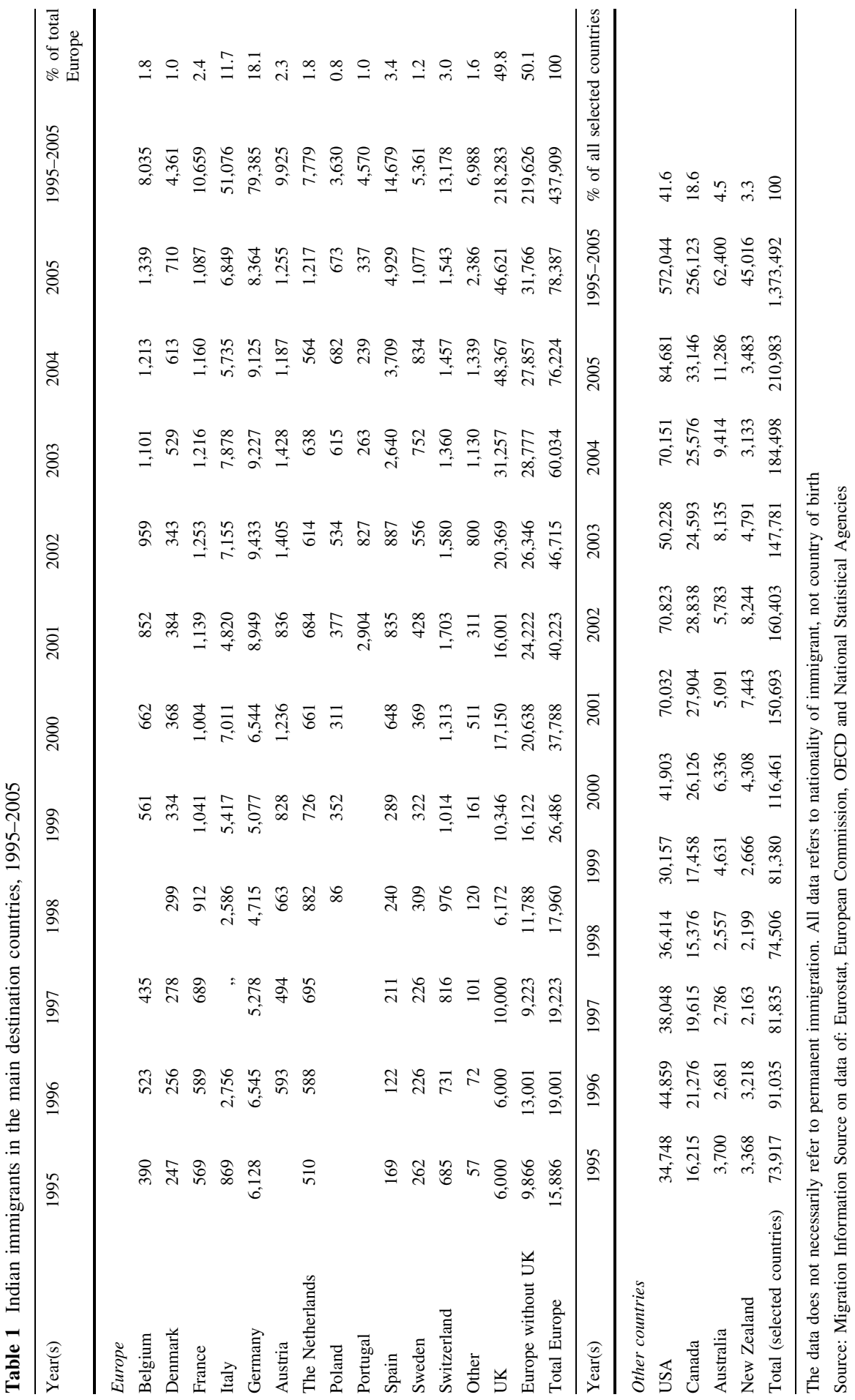


Munshi 2012). Not to mention a recent survey of Indians working in managerial roles for US firms, which found that $68 \%$ said they plan to move back to their homeland in the near future, while $12 \%$ had already packed their bags, or wouldn't hesitate to do so (ILO 2009).

The second reason, and in some respects the more important, is India's significant economic development, seen in recent years in certain strategic sectors including IT, biotechnology, research and development, textiles and business process outsourcing (BPO). ${ }^{3}$ It is precisely the fact that India has managed to establish itself among the world-leaders in BPO, which makes it a destination of particular interest for highlyskilled workers from abroad. This phenomenon is accentuated by the fact that, in a break with past common practice, salaries offered by Indian multinationals are now not so dissimilar to those offered by large American or European firms.

There is one difference, which is not at all secondary: the fact that Indian salaries are growing at a much faster rate than the increase of wages in the US. The rate is 13 to 1 (Seghal 2004).

In addition to the developments on Indian soil, with the arrival of highly-qualified migrants from other countries and the return of India's own skilled migrants, emphasis should also be placed on the role of qualified personnel abroad, in other words, the Indian diaspora.

\section{The Pervasive Soft Power of the «Indiaspora»}

Countries can benefit from their qualified human capital abroad in three ways: through remittances, investment flows or from the expertise and knowledge of skilled migrants that have returned home. These are normally the arguments used to show the positive role played by a country's own qualified migrants abroad (and in the case of their more or less stable return home, referred to as the brain return or brain circulation). These factors, it is argued, counter-balance the potentially negative effects of brain drain. This is true mainly for those countries, with a small population or those with phases of political instability and/or with scarce career prospects, that have actually the highest rates of brain drain. In these cases, the beneficial effects of remittances, investments and sharing of knowledge from skilled migrants can be considerable and can help to counter the negative effects of brain drain and, in general, can support the economies of those countries.

Can the contribution of qualified migrants be considered significant, even in the case of a country such as India with more than one billion inhabitants and in the process of full economic expansion? That is to say, how much is the contribution of skilled migrants compared to the contribution of migrants in general? To what extent is their contribution correlated to the size of population and the economy?

Let's start by saying that in India, remittances reached \$55 billion in 2010 (World Bank 2011), making it the biggest receiver of remittances in the world. These payments are more than three per cent of national GDP. In absolute terms, as shown by Fig. 1, this is a growing trend that, since 2004, has contributed between $\$ 25$ and

\footnotetext{
${ }^{3}$ A term that refers to companies that carry out processes on behalf of other companies.
} 


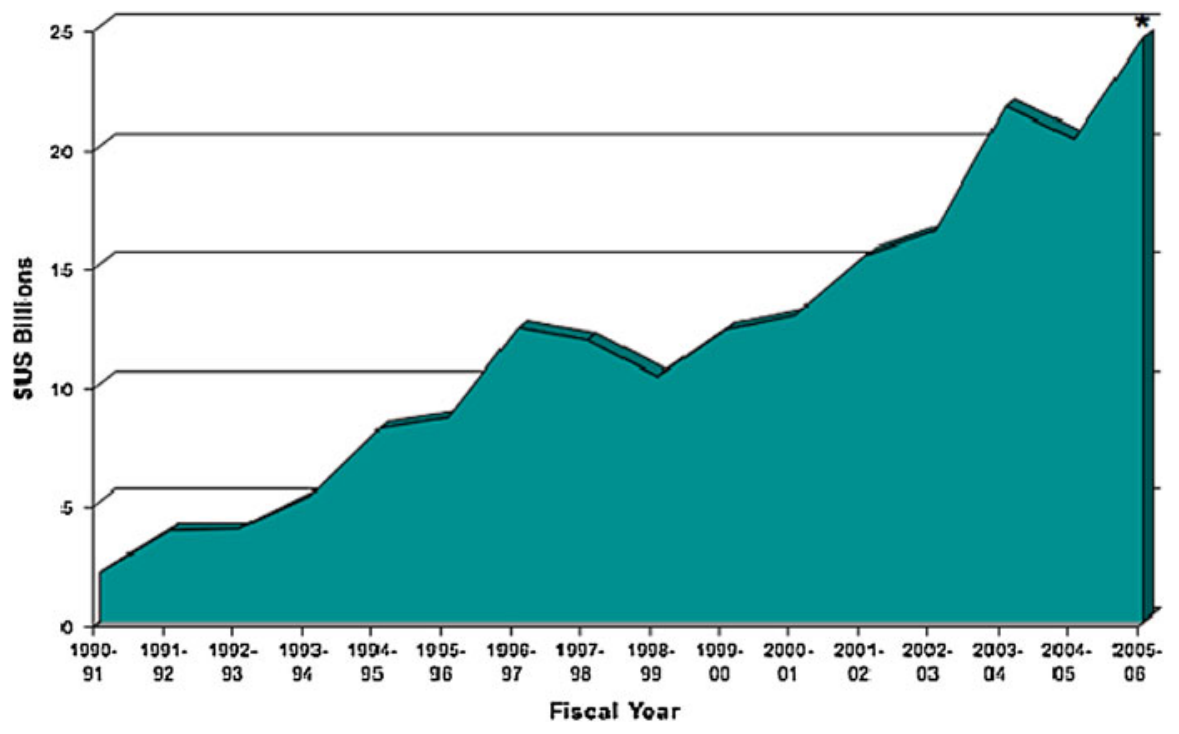

Fig. 1 Remittances to India, \$ billions, from 1990-1991 to 2005-2006. Source: Migration Information Source on data from the National Bank of India

30 billion a year (Chishti 2007). Furthermore, remittances have helped India to reduce the deficit on its balance of payments (Mani 2009).

Aggregated data from the diaspora apart, it is also interesting to understand the contribution of qualified migrants (compared to unqualified migrants) to the economic development of their own countries, beginning with remittances, which are the most visible channel through which money is sent to families back home.

In a recent, interesting analysis (Bollard et al. 2011), carried out on a database of 33,000 immigrants in 11 OECD countries, it was verified that qualified migrants send more remittances per person, compared to less qualified migrants. The average sum of remittances sent by migrants with tertiary education (classification according to UNESCO's ISCED, International Standard Classification of Education) is about $\$ 1,000$ a year. This is of course intuitive: qualified migrants earn more than those who are less qualified.

More interesting, in the context of this article, is that the analysis reveals a strong negative correlation between income levels in the migrant's country of origin and the probability that the migrant sends remittances (Fig. 2). That is to say, the lower the gross national income per capita of the country, the higher the probability that the country's qualified migrants abroad will send remittances. In this sense, it's not the size of a country's population that makes the difference, but rather the low income level elicits a bigger quantity of remittances.

The sum of remittances, then, is significantly higher from qualified migrants from countries with high levels of brain drain. More precisely, between 68 and $93 \%$ of qualified migrants from developing countries send about $\$ 5,000$ in remittances a year (Gibson and McKenzie 2010). Higher brain drain, low income per capita and dimension of the diaspora thus explain India's global primacy in terms of remittances. 


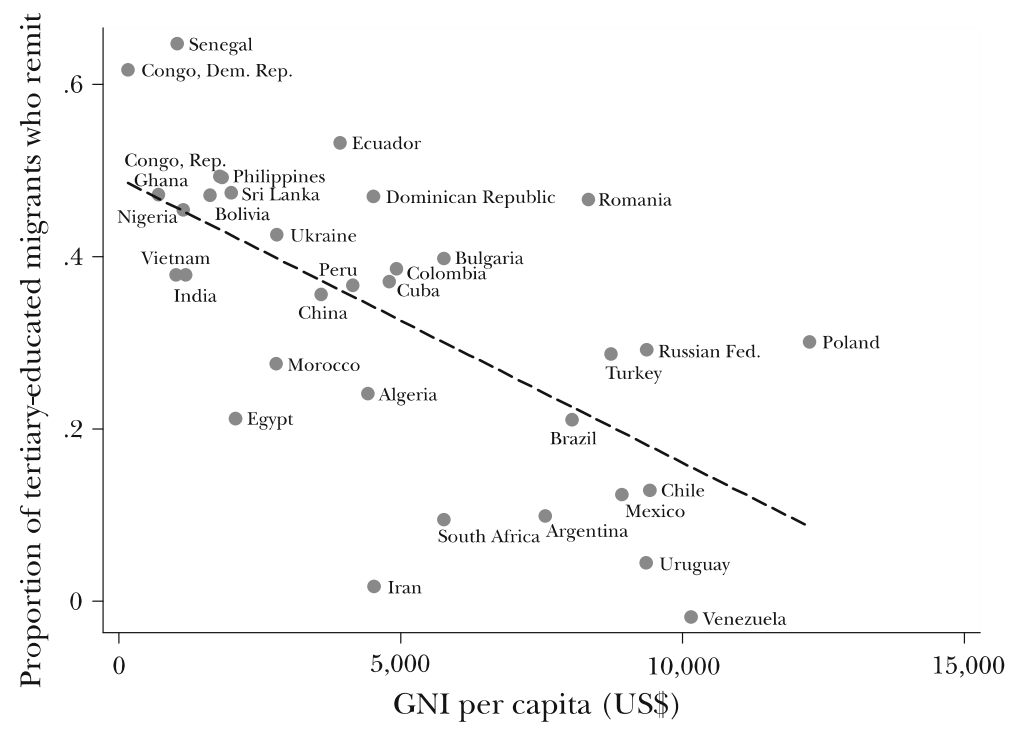

Fig. 2 Correlation between proportion of qualified migrants sending remittances and gross national income per capita in US\$. Source: Database of Bollard, McKenzie, Morten and Rapoport, and World Development Indicators

Other studies (Kugler and Rapoport 2007; Javorcik et al. 2011) have shown a positive connection between the number of qualified migrants a country has in the US and the level of foreign direct investment (FDI) that the US puts into that country. As already shown, with about $40 \%$ of the Indian diaspora based in the US, it is easy to see how this could influence the decisions of US investors.

The same cannot be said, however, of FDI from Indian brands abroad back into the homeland-investments from this quarter have not been as high as expected after the liberalisation of the 1990s. The Indian diaspora has invested modestly in the Indian economy ( $3 \%$ of gross capital formation), particularly when this figure is compared with China's FDI from the Chinese diaspora (10.1\% of GCF), (Roy and Banerjee 2007). Some analysts (Sinha Palit and Palit 2011), however, note possible interference based on a soft power strategy, practised by the Chinese diaspora in Southeast Asia.

With regards to the transfer of technology and the spread of knowledge in the territory, the emergence of India's competitive IT sector is also noteworthy, and the primary role of India's diaspora in this sector's success, having capitalised on their positive experience in the US (Pandey et al. 2004). Highly-skilled Indian migrants have played a leading role in forging the development of the burgeoning Indian IT industry.

Other than the economic aspects, the Indian diaspora is also politically relevant on the international geopolitical stage. Khanna (2005) argues that the potent cocktail of culture and technology, possible thanks to globalisation, allows Indians across the world to be influential in a space that is both imaginary and real, but is in any case shared. The cosmopolitan Indian culture, which Khanna refers to as «Bollystan», is 
emerging organically as a new model of sovereignty that transcends geography. Also interesting is a comment from Khadria (2007), which reflects on the skilled component of the Indian diaspora and wonders whether India will know how to transform these geographically-spread skills into a «Great Off-White Hope» for the new century.

In short, the soft power of the «Indiaspora» (Khadria 2001) seems to be based mainly on Indian culture, so diverse and fascinating, on the political values of the biggest democracy in the world and, last but not least, on the technological competence of Indians. However, also the hard power should not be overlooked: India has a vast territory, the world's second biggest population (which looks likely to become the biggest within a few decades), and the third biggest army in the world.

As has been rightly noted (Purushothaman 2010), this promising prospect could be thrown into doubt by some of India's problems, including its low ranking in the Human Development Index (HDI), internal social and ethnic conflicts as well as potential external military conflicts.

In any case, there is no doubt that the Indian diaspora and especially its qualified part, represents for India a competitive advantage in the international arena. In this framework, which role the Indian politics plays?

\section{Transformation of Migratory Flows and the Role of New Delhi}

A particularly striking facet of Indian migration, more striking than the metamorphosis itself, is that Indian politics has played a rather marginal role in shaping the phenomenon. While countries such as Australia, Canada and the US invest historically vast sums of public resources in attracting overseas talent and facilitating the return of their own talent-more recently this is also true of China (Giordano and Pagano 2009) — the Indian government has done, substantially, little or nothing. It has, in effect, delegated this role to the market.

Why, then, has the New Delhi administration not put in place policies aimed at attracting the best international skills and, more to the point, facilitated the repatriation of qualified Indian emigrants from abroad?

Regarding the first point, much is due to the fact that India has the second biggest workforce in the world, amounting to 518 million people, part of which is unemployed and living in poverty. As regards the second point, however, it is worth reiterating the comments made previously.

The paragraphs above explain why the Indian government has never implemented policies aimed at encouraging the return of its expatriates. Rather, in recent years it has adopted ad hoc measures, the only purpose of which has been to better manage the huge sums sent by remittance every year. In short, the government has been more concerned with securing the investments of the Indian diaspora, rather than attracting the return of expatriates themselves.

This has been demonstrated by at least three initiatives that have been promoted in recent years by the Indian government.

The first dates from 2003, the year in which the Annual Diaspora Conference was first held. The Pravasi Bharatiya Divas (Non-resident Indian Day) is promoted with 
the aim of creating a community among expatriates, political authorities and the principal Indian economic players. To give an idea of the importance of this event, it is enough to note that annual attendees include India's president, prime minister, secretaries of the main unions and the country's most important businessmen, with 1,000-1,500 representatives of the Indian diaspora worldwide (Naujoks 2009). The topic of debate is always the same: how and where to invest large sums of expatriate remittance.

The second initiative came in 2004, when the Ministry of Overseas Indian Affairs was created. One of the initiatives it promotes is the so-called «Know India Program». The project is dedicated to successful young expatriates and a prize is awarded each year for economic or scientific achievements.

In 2005, following on from the introduction of the Person of Indian Origin Card (PIO Card) in 1999, Overseas Citizenship of India (OCI) was introduced. Both schemes involve special identity documents that give equal rights to Indian expatriates and Indians resident domestically. An exception is the right to vote, actively or passively, and the right to take a seat in government.

Two years ago Prime Minister Manmohan Singh said: «Today in India we are experiencing the benefits of remittance flows, of investments and of skills derived from the Indian diaspora. The problem of brain drain has been happily transformed into the possibility of brain gain» (Indian government 2010).

\section{Conclusions}

To summarise, it is possible to argue that the trend in recent years, of a limited but steady reversal of the migratory flows towards India, with the arrival of qualified personnel from overseas and the return of many Indian emigrants, has been driven mainly by economic factors. Of note among these economic factors, other than those already mentioned above, is what can be called, without fear of exaggeration, the Copernican revolution of the 1990s.

At the beginning of that decade, the government instigated a far-reaching liberalisation process of the Indian market, which contributed significantly to making the country more attractive to foreign investors. This fostered a change of pace that meant India is today considered among the main world powers, due to its leadership in key sectors such as IT.

Politics, on the other hand, has focused its efforts, as we have noted, in the field of evaluating and reinforcing the socio-economic role of the Indian diaspora (Chanda and Sreenivasan 2009). Its principle objective, though, has not been to encourage a repatriation of citizens, but to better manage and channel the considerable economic resources they send by remittance.

It is clear that if India wants to continue its rise in the international arena, it will, in addition to addressing the problems noted above, need to focus mainly on reinforcing its human capital (Kaul 2006). This is of course true for all countries, but more so for India, considering the structure of its economy's strategic industries and the potential quality of its large population. 


\section{References}

Bollard A, McKenzie D, Morten M, Rapoport H (2011) Remittances and the brain drain revisited: the microdata show that more educated migrants remit more. World Bank Econ Review, vol 25(1), May, Oxford University Press, Oxford, pp 132-156

Buga N, Meyer JB (2012) Indian human resources mobility: brain drain versus brain gain. CARIM-India RR 2012/04, Robert Schuman Centre for Advanced Studies, European University Institute, San Domenico di Fiesole, Florence. http://www.india-eu-migration.eu/media/CARIM-India-2012\%20\%2004.pdf. Accessed 3 September 2012

Chanda R, Sreenivasan N (2009) India's experience with skilled migration. In: Kuptsch C, Pang E (eds) Competing for global talent, ILO, Geneva, pp 215-256

Chishti M (2007) The rise in remittances to india: a closer look. February, Migration Information Source, Migration Policy Institute, Washington, DC. http://www.migrationinformation.org/Feature/display. cfm?ID=577. Accessed 3 September 2012

Counihan CR, Miller MJ (2006) Competing for global talent in an age of turbulence. In: Kuptsch C, Pang E (eds) Competing for global talent, ILO, Geneva, pp 259-275

Gibson J, McKenzie D (2010) The economic consequences of "Brain Drain" of the best and brightest: microeconomic evidence from five countries. Policy Research Working Paper 5394, World Bank, Washington, DC

Giordano A, Pagano A (2009) Brain Circulation e Sviluppo Economico: La Cina Tra Mobilità Intellettuale e Capacità Innovativa. Bol Soc Geog Italiana, vol (13)2, April-June, Società Geografica Italiana, Rome, pp 113-128

Hawthorne L (2008) The growing global demand for students as skilled migrants. Migration Policy Institute, Washington, DC. http://www.migrationpolicy.org/transatlantic/intlstudents.pdf. Accessed 3 September 2012

International Labour Organisation (2009) Competing for global talent. ILO, Geneva

Javorcik B, Özden Ç, Spatareanu M, Neagu C (2011) Migrant networks and foreign direct investment. J Dev Econ 94(2):231-241

Kaul S (2006) Higher education in India: seizing the opportunity. Working Paper No. 179, May, Indian Council for Research on International Economic Relations, New Delhi

Khadria B (2001) India: country study—skilled labour migration (the "Brain Drain") from India: impact and policies. Jawaharlal Nehru University, New Delhi

Khadria B (2006) India: skilled migration to developed countries, labour migration to the gulf. Jawaharlal Nehru University, New Delhi

Khadria B (2007) Conceptualising the typologies of Indian diaspora in international economic relations: 'Tinker, Tailor, Soldier, Spy', or a 'Great Off-White Hope' of the new century? ISAS Working Paper No 19, January, Institute of South Asian Studies, Singapore

Khanna P (2005) Bollystan: India's Diasporic Diplomacy. In: Khilnani S (eds) India as a new global leader. Foreign Policy Centre, London, pp 16-26. http://www.isn.ethz.ch/isn/Digital-Library/ Publications/Detail/?ots591=0c54e3b3-1e9c-be1e-2c24-a6a8c7060233\&lng=en\&id=23654. Accessed 3 September 2012

Kugler M, Rapoport H (2007) International labor and capital flows: complements or substitutes? Econ Lett 94(2):155-162

Lamont J, Munshi L (2012) The rigours of India's repatriates, Financial Times, 25 April. http://www. ft.com/intl/cms/s/0/5e5a0158-8d73-11e1-9798-00144feab49a.html\#axzz25Q8MajvL. Accessed 3 September 2012

Lowell L, Findlay A (2001) Migration of highly skilled persons from developing countries: impact and policy responses. International Migration Papers, Synthesis Report n 44, ILO, Geneva

Lucas R (2008) International labor migration in a globalizing economy. Trade, Equity, and Development Program, n.92, July, Carnegie Endowment for International Peace, Washington, DC

Mahroum S (1999) Highly skilled globetrotters: mapping the international migration of human capital. R \& D Manag (30)1:23-31

Mani S (2009) High skilled migration from India, an analysis of its economic implications. Working Paper 416, Centre for Development Studies, Trivandrum

Naujoks D (2009) Emigration, immigration and diaspora relations in India. Migration Policy Institute, October, Washington, DC. http://www.migrationinformation.org/feature/display.cfm?ID=745. Accessed 3 September 2012 
Pandey A, Aggarwal A, Devane R, Kuznetsov Y (2004) India's transformation to knowledge-based economy-evolving role of the Indian diaspora. July 21, Evalueserve. http://info.worldbank.org/ etools/docs/library/152386/abhishek.pdf. Accessed 3 September 2012

Purushothaman U (2010) Shifting perceptions of power: soft power and India's foreign policy. J Peace Stud 17(2-3):10-11

Roy J, Banerjee P (2007) Attracting FDI from the Indian diaspora: The way forward. Confederation of Indian Industry, New Delhi. http://www.oifc.in/Uploads/MediaTypes/Documents/AttractingFDI FromIndianDiaspora.pdf. Accessed 3 September 2012

Seghal M (2004) Foreign pros seeking jobs in India. Rediff India Abroad, February 11. http://www.rediff.com/money/2004/feb/11bpo1.htm. Accessed 3 September 2012

Semple K (2012) Many US immigrants' children, seek american dream abroad. New York Times, 16 April. http://www.nytimes.com/2012/04/16/us/more-us-children-of-immigrants-are-leaving-us.html? _r=2\&hp. Accessed 3 September 2012

Sinha Palit P, Palit A (2011) Strategic influence of soft power: inferences for India from Chinese engagement of south and southeast Asia. ICRIER Policy Series No 3, August, Indian Council for Research on International Economic Relations, New Delhi

Wihtol de Wenden C (2009) La globalisation humaine. PUF, Paris

World Bank (2011) Migration and remittances factbook 2011, 2nd edn. World Bank, Washington, DC 